Print ISSN: 2234-3040 / Online ISSN 2234-3059

doi:10.13106/eajbm.2018.vol8.no2.33

\title{
Investigating the Determinants of Public Servant Income Management
}

\author{
Md Lazim Mohd Zin*, Hadziroh Ibrahim**, Ahmad Zafwan Sulaiman*** \\ Received: February 26, 2018. Revised: March 29, 2017. Accepted: April 15, 2018.
}

\section{Abstract}

\begin{abstract}
Purpose - This study aims to examine the determinants of income management of the public servant. Three independent variables are examined such as attitude towards money, financial capability and debt management while the dependent variable is financial wellbeing of public servants.

Research design, data, and methodology - Quantitative research is applied in this study, and data are collected by using cross sectional approach. Survey questionnaires are obtained from 270 respondents, which represents $79 \%$ response rate. The multiple regressions are used to examine the influence of attitude towards money, financial capability and debt management towards financial wellbeing.

Results - The result of the multiple regression indicated positive influences of attitude towards money and financial capability on financial wellbeing. However, debt management found no significant influence on financial wellbeing.

Conclusions - Research findings show that people have different attitudes towards money and different trends of expenditure. It is also crucial to be highlighted that employees' attitude and financial capability have a greater influence on overall satisfaction with employees' financial wellbeing. Some would want to show off their luxury items they bought to close friends or relatives and some are very prudent in making expenditures even for necessity items.
\end{abstract}

Keywords: Attitudes Towards Money, Financial Capability, Income Management, Public Servants.

JEL Classifications: M5, M21.

\section{Introduction}

Many households accumulate debt from a variety of sources including mortgages, student loans and consumer debt. Many Malaysian consumers seem to display excessive buying behavior, commonly known as 'compulsive buying'. Easy availability of credit and compulsive buying has led to many adverse consequences such as addiction to shopping and excessive debt. According to statistics from Malaysia Department of Insolvency, there were 60 Malaysians declaring bankruptcy every day and 19,575 were categorized

* First Author, Corresponding Author, School of Business Management, College of Business, Universiti Utara Malaysia, 06010, Sintok, Kedah, Malaysia.

Tel: +60-04-9287526, E-mail:lazim@uum.edu.my

** School of Business Management, College of Business, Universiti Utara Malaysia, 06010, Sintok, Kedah, Malaysia.

E-mail: hadziroh@uum.edu.my

*** Unit Pemodenan Tadbiran dan Perancangan Pengurusan Malaysia (MAMPU), Kompleks Jabatan Perdana Menteri, Pusat Pentadbiran Kerajaan Persekutuan, 62502 Putrajaya, Malaysia. bankrupt in 2012 (Malaysia Department of Insolvency, 2012). Based on this data, there is growing concern in Malaysia about income management especially in household debt and overall financial wellbeing of Malaysians. With the rising cost of food, petrol and other necessities, it is important to manage an income well in order to live a sustainable life. However, it has been observed in recent years that public servants tend to be in serious financial difficulties especially in the early years of employment. It has also been noted that public servants with financial problems intend to be more desperate to resolve their financial predicament.

\subsection{Problem Statement}

Lately, there has been much attention given to financial problems among Malaysians. Financial problems especially, among civil servants, keep increasing over time and underscore a very disturbing phenomenon. Based on the statistics obtained from the Credit Management and Counseling Agency (AKPK), up to May 31, 2014, more than 
$<$ Table 1> Age Statistics of People Enrolled in AKPK's Debt Management Program

\begin{tabular}{|c|c|c|c|c|c|c|c|c|}
\hline \multirow{2}{*}{ At End } & \multicolumn{2}{|c|}{$20-30$} & \multicolumn{2}{|c|}{ 31- 40} & \multicolumn{2}{|c|}{$>40$} & \multicolumn{2}{|c|}{ Total } \\
\hline & No & $\%$ & No & $\%$ & No & $\%$ & No & $\%$ \\
\hline 2007 & 3516 & 71.1 & 745 & 15.1 & 683 & 13.8 & 4944 & 100 \\
\hline 2008 & 4910 & 35.1 & 4829 & 34.5 & 4248 & 30.4 & 13987 & 100 \\
\hline 2009 & 7864 & 25.2 & 12290 & 39.4 & 11021 & 35.4 & 31175 & 100 \\
\hline 2010 & 10526 & 22.7 & 18479 & 39.8 & 17451 & 37.6 & 46456 & 100 \\
\hline 2011 & 12876 & 20.8 & 24756 & 39.9 & 24406 & 39.3 & 62038 & 100 \\
\hline 2012 & 14761 & 19.2 & 30782 & 40.0 & 31418 & 40.8 & 76961 & 100 \\
\hline 2013 & 16336 & 17.7 & 36916 & 39.9 & 39220 & 42.4 & 92472 & 100 \\
\hline 2014 & 17096 & 17.1 & 39811 & 39.8 & 43048 & 43.1 & 99955 & 100 \\
\hline
\end{tabular}

271,694 individuals have counseling services from AKPK where 108,818 of them were assisted through the Debt Management Program. In addition, a large group of those with financial related problem is made up of younger adults and more likely from the junior executive level. Those listed in $\langle$ Table $1>$ are some of the public servants who want to recover from their financial problems but there are many who do not seek such professional advice. Some of those who did not seek help might get into financial exclusion, became bankrupt, face job termination or resort to financial fraud in the workplace. There have a lot of cases of financial fraud involving public servant, ranging from those in lower ranks to top management; so yes; even those in top executive positions are not immune to financial difficulties.

Surprisingly, there is scarce research on the financial well-being among Malaysians especially employees, while workers' debt in the current situation is growing more rapidly than inflation. With decreasing employment prospects, income instability and the eroded purchasing power of Malaysian households, workers' financial security has become a main concern among policy makers (Fazli \& Leila, 2003). Thus, in this study, the main objective is to identify the determinants of public servants' income management by focusing on attitude towards money, financial capability and debt management, while the dependent variable is financial wellbeing of public servants.

\section{Literature Review}

\subsection{Financial Wellbeing}

Financial wellbeing is defined as an individual's satisfaction with income and savings, as well as perceptions of opportunities, and the ability to make ends meet, a sense of material security and a sense of fairness of the reward distribution system. Through evolution of studies, the definition has been broader referring financial wellbeing as a subjective perceptions and objective indicators of individuals' personal financial status. Subjective perceptions include individuals' satisfaction with their current and future financial situation. Objective indicators of financial circumstances include measures such as income, debt, savings and aspects of financial capability such as knowledge of financial products and services, planning ahead and living within the budget. As overall, financial well-being describes the happiness and the satisfactory levels with the family's financial situations (Kim, Garman, \& Sorhaindo, 2003; Porter \& Garman, 1993). Another term of financial wellbeing is encompassing financial competence and capability in the sense of making ends meet, healthy financial behavior and abreast of financial updates (Cox, Hooker, Markwick, \& Reilly, 2009).

Past researches in this area has been conducted piecemeal such as evaluation on demographic characteristics, socioeconomic status, consumption on durable goods, satisfaction with consumption, family financial management and household situation. Investigations were mostly done to evaluate the role of individual perceptions of the financial situation on wellbeing. Previous findings show that improved financial management skills, cash management strategies and futuristic planning styles may help people avert financial difficulties and increase perceived financial wellbeing. Decreased financial wellbeing may result from the limited use of certain financial management behaviors that are believed by experts to increase financial success (Porter \& Garman, 1993). There are many factors related to the household income management of young executives in either the private or public services. Research on household income management has been done by many researchers using financial wellbeing as an important factor. Ideally, junior executives are mostly consists of person in youth ages or fresh graduates. Statistically, half of Malaysian population consists of youth workers which compose of 11.65 million. Therefore, there is significant interest in determining the factors related to household income management especially in junior executives in public service. Research by Nuraini et al. (2013), have identified nine factors in determining the financial wellbeing such as financial literacy, attitude towards money, self-esteem, financial management practice, financial skill, financial stress, financial problem, financial capability and debt management. However, given the limited time, research of this study will 
consists of only three of the factors which are attitude towards money, financial capability and debt management.

\subsection{Attitude towards Money}

Motives underlying money attitudes range from striving for status and power and enhancing self-worth (Lindgren, 1980) to searching for security and satisfying one's needs (Knight, 1968). Because of the paradoxical nature of money, it is not surprising to hear that money does mean different things to different people. To support this argument, past findings found that employed people tended to have a more positive attitude toward money than unemployed people (Wernimont \& Fitzpatrick, 1972). Needless to say, there is no general statement about the meaning or the role of money for the population in general (Christopher, Marek, \& Carroll, 2004). Attitudes toward money relates to the financial wellbeing since the measurement of the factor will acknowledge to which one feels that the amount of money a person has is a result of effort and ability (Furnham, 1984). As such, this study proposes that:

$<\mathrm{H} 1>$ There is significant relationship between attitude towards money and the financial wellbeing among public servants.

\subsection{Financial Capability}

Scholars, policy makers and educators recently introduced the concept of "financial capability" to describe a person's ability to successfully manage personal financial demands (Remund, 2010). Lusardi (2011) stated that there are important gaps in the financial capability of Americans. Individuals with higher levels of financial capability possess the knowledge, skills, and access to tools to effectively manage their finances to foster long-term well-being (Department of the Treasury, President's Advisory Council on Financial Capability, 2012). Serido, Shim, and Tang (2013) in their studies have found there is a significant correlation between financial capability and financial wellbeing in their study of young adults in America. Drawing upon the abovementioned empirical support, it is posited that:

$<\mathrm{H} 2>$ There is significant relationship between financial capability and the financial wellbeing among public servants.

\subsection{Debt Management}

There is significant evidence in a study conducted by Williams, Haldeman, and Cramer (1996) to show the relationship between debt management and financial problem. Their findings are that individuals who have a lot of financial problems tend to face with serious debt management problems. The study of Roberts and Jones
(2001) found that young workers recorded the highest statistical in financial difficulties and dissatisfaction about finance. In the United States, it is found that $60 \%$ of young people aged between 18-39 years facing higher education debt and affected their affordability to repay the loan (Whitsett, 2012). Another research by Thums, Newman, and Xiao (2008) found that the younger generation aged between 20-24 years had financial problems and have less confidence about debt management. In conclusion, the study of Debt management especially in junior level executives of public services is very much needed. This is due to the increased burden of debt, especially by young people who just newly landed a job with basic income which is significantly low and they cannot ensure long-term stability for themselves and their families (Fazli \& Mumtazah, 2010). Based on this discussion, the following hypothesis is proposed:

$<\mathrm{H} 3>$ There is significant relationship between debt management and the financial wellbeing among public servants.

\section{Methodology}

The study was conducted based on quantitative research approach. The unit of analysis of the study is individual who work in public service from junior executive of grade 41 in various ministries. The questionnaire is adapted from Money Beliefs and Behavior Items (Furnham, 1984). The questionnaires consist of three independent variables which are attitude towards money, financial capability and debt management. There are 24 questions measuring the attitude towards money, 20 questions measuring the financial capability and 13 questions measuring the debt management. These questions were measured by using a five-point Likert Scale ranging from 1 = "Strongly Disagree" to $5=$ "Strongly Agree". There is only one dependent variable in this research which is financial wellbeing. It was measured with 12 questions by using five-point Likert Scale ranging from $1=$ "strongly dissatisfied" to $5=$ "strongly satisfied".

The population of this research is public servant of Administrative and Diplomatic service officers (or well known in Malay as PTD) in Grade M41 at various ministries. This group was selected as it is consistent with the AKPK's reports and findings of the secondary data by media and news reports, in that this group is the one which is most often faced with financial problems or over-indebtedness. Every government scheme of Grade 41 has an almost similar pay scale and this allows the researcher to target one particular group which is in the Administrative and Diplomatic service or scheme in which the researcher has the opportunity and the access to collect the data in a limited time frame. Putrajaya was also chosen because it is 
the only Federal Territory in Malaysia where most of the residents are public servants. The total number of PTD M41 officers in Malaysia is 3420 and according to Krejcie and Morgan (1970), the appropriate sample size for a population more than 3000 but not exceeding 3500 are 341 . This study also uses proportionate stratified random sampling when the purpose of the study is to assess differential parameters in subgroups of population and all subgroups have an equal number of elements. After the number of samples have been identified using proportionate stratified random sampling, the sample will then be selected by systematic random sampling in which the samples are chosen with $n$ being equal to 4 which is $4,8,12,16$ and so on. There are two types of the analysis used in the study namely descriptive and inferential analysis.

\section{Findings}

\subsection{Profile of Respondents}

From 341 questionnaires as the population sample, only 270 questionnaires comprise of $79.18 \%$ were returned and valid for data analysis. Referring to <Table 1>, most of the respondents or $71.1 \%$ were female and male respondents mark up at $28.9 \%$. Most of the respondents' age ranged from 26 to 30 years $(74.9 \%)$, other age groups were, 25 years below $(3.7 \%), 31$ to 35 years old $(18.1 \%), 36$ to 40 years old $(2.2 \%)$ and there is only 1 respondent age 46 years and above (0.4\%). The majority (90.0\%) of respondents were Malay and the others were Chinese $(6.3 \%)$, Indian $(2.2 \%)$ and others $(1.5 \%)$. The majority or $60.5 \%$ of them were married while $39.1 \%$ were still single and there was 1 person who was a widower $(0.4 \%)$. There were 23 Ministries involved in this research and the highest number of respondents (41.7\%) was from Prime Minister's Department. Most of them (88.9\%) had been working for between 1 to 5 years. Some of them (4.4\%) however had been in for less than a year. Those with 6 to 10 years of service made up $6.6 \%$ of the respondents.

Findings reveal that $40.6 \%$ of the respondents were earning between RM3,001 to RM3,500 per month. The second largest group representing $35.8 \%$ of respondents earned between RM3,501 to RM4,000. Those earning $\mathrm{RM} 4,001$ to $\mathrm{RM} 4,500$ made up $15.5 \%$ whereas those earning $\mathrm{RM} 2,501$ to $\mathrm{RM} 3,000$ made up $6.6 \%$ of the respondents. Only $1.5 \%$ of the respondents were earning more than RM4,501 and above per month. As for total expenditure per month, $29.5 \%$ of the respondents indicated that they spent more than RM3,001, whereas $27.3 \%$ acknowledged that they spent between RM2,501 to RM3,000 per month. A further $16.2 \%$ were found to spend between RM2,001 to RM2,500. A total of $15.9 \%$ of the respondents admitted to spending between RM1,501 to RM2,000 per month. Only $8.9 \%$ were found to have a monthly expenditure of RM1,001 to RM1,500 and the figure for those with a monthly expenditure below RM1,000 was $2.2 \%$.

<Table 2> Respondents' profile

\begin{tabular}{|c|c|c|}
\hline \multicolumn{3}{|l|}{ Gender } \\
\hline Male & 78 & 28.9 \\
\hline Female & 192 & 71.1 \\
\hline \multicolumn{3}{|l|}{ Age } \\
\hline 25 years and below & 10 & 3.7 \\
\hline $26-30$ years & 203 & 74.9 \\
\hline 31 - 35 years & 49 & 18.1 \\
\hline 36 - 40 years & 6 & 2.2 \\
\hline $41-45$ years & 2 & 0.7 \\
\hline 46 years and above & 1 & 0.4 \\
\hline \multicolumn{3}{|l|}{ Race } \\
\hline Malay & 244 & 90.0 \\
\hline Chinese & 17 & 6.3 \\
\hline Indian & 6 & 2.2 \\
\hline Others & 4 & 1.5 \\
\hline \multicolumn{3}{|l|}{ Marital Status } \\
\hline Bachelor & 106 & 39.1 \\
\hline Married & 164 & 60.5 \\
\hline Widow & 1 & .4 \\
\hline \multicolumn{3}{|l|}{ Highest Education } \\
\hline Advance Diploma / Degree & 237 & 87.5 \\
\hline Master's Degree & 34 & 12.5 \\
\hline \multicolumn{3}{|l|}{ Ministries } \\
\hline Prime Minister's Department & 113 & 41.7 \\
\hline Sport \& Youth & 2 & .7 \\
\hline Home Affair & 15 & 5.5 \\
\hline Rural \& Regional Development & 6 & 2.2 \\
\hline Works & 4 & 1.5 \\
\hline Urban Wellbeing, Housing \& Local Government & 1 & .4 \\
\hline Health & 13 & 4.8 \\
\hline Finance & 20 & 7.4 \\
\hline Communication \& Multimedia & 1 & .4 \\
\hline Foreign Affair & 14 & 5.2 \\
\hline Education & 21 & 7.7 \\
\hline Tourism \& Agriculture & 6 & 2.2 \\
\hline Women, Family \& Community & 4 & 1.5 \\
\hline Transport & 14 & 5.2 \\
\hline International Trade \& Industry & 6 & 2.2 \\
\hline Domestic Trade, Cooperative and Consumerism & 7 & 2.6 \\
\hline Defence & 1 & .4 \\
\hline Agriculture \& Agro-Based Industry & 5 & 1.8 \\
\hline Plantation Industries \& Commodities & 3 & 1.1 \\
\hline Science, Technology \& Innovation & 4 & 1.5 \\
\hline Natural Resources \& Environment & 5 & 1.8 \\
\hline Federal Territory & 3 & 1.1 \\
\hline Energy, Green Technology \& Water & 3 & 1.1 \\
\hline \multicolumn{3}{|l|}{ Service Period } \\
\hline Below 1 year & 12 & 4.4 \\
\hline $1-5$ years & 241 & 88.9 \\
\hline $6-10$ years & 18 & 6.6 \\
\hline
\end{tabular}




\begin{tabular}{|l|c|c|}
\hline Total Salary per Month & & \\
\hline RM2,501 - RM3,000 & 18 & 6.6 \\
\hline RM3,001 - RM3,500 & 110 & 40.6 \\
\hline RM3,501 - RM4,000 & 97 & 35.8 \\
\hline RM4,001 - RM4,500 & 42 & 15.5 \\
\hline RM4,501 and above & 4 & 1.5 \\
\hline Total Expenditure per Month & & \\
\hline RM1,000 and below & 6 & 2.2 \\
\hline RM1,001 - RM1,500 & 24 & 8.9 \\
\hline RM1,501 - RM2,000 & 43 & 15.9 \\
\hline RM2,001 - RM2,500 & 44 & 16.2 \\
\hline RM2,501 - RM3,000 & 74 & 27.3 \\
\hline RM3,001 and above & 80 & 29.5 \\
\hline Total Savings per Month & & \\
\hline RM100 and below & 55 & 20.3 \\
\hline RM101 - RM200 & 63 & 23.2 \\
\hline RM201 - RM300 & 62 & 22.9 \\
\hline RM301 - RM500 & 45 & 16.6 \\
\hline RM501 - RM1,000 & 37 & 13.7 \\
\hline RM1,001 and above & 9 & 3.3 \\
\hline
\end{tabular}

\subsection{Multiple Regression Analysis}

To draw accurate conclusions about the regression analysis, assumptions of linearity, homoscedasticity, normality, independence of the error terms, and multicollinearity need to be examined. Variance inflation factor (VIF) and tolerance statistics are the two statistical methods that can be used to assess multicollinearity. It is generally believed that any VIF value exceeds 10 and tolerance value below than .10 indicates a problem of multicollinearity. In addition, Durbin-Watson can be used to test independence of error terms. If the Durbin-watson value is between 1.5 and 2.5, the assumption of independence of the error terms is not violated. It this study, evaluation on assumptions of linearity, homoscedasticity, normality, independence of the error terms, and multicollinearity revealed no significant violation of assumption.

Referring to $<$ Table $2>$, the result shows that the $R^{2}$ is .232. This implies that the three independent variables explained about $23.2 \%$ of the variance in the dependent variable of financial wellbeing. The largest beta coefficient was .344 which was attitude towards money. This implies that the independent variable of attitude towards money makes the strongest contribution to explain the dependent variable of financial wellbeing. It suggests that one standard deviation increase in attitude towards money resulted in a .344 standard deviation increase in financial wellbeing. The second highest beta value of .274 was obtained on the independent variable of financial capability. It also suggested that a one standard deviation increase in financial capability is followed by .274 standard deviation increase in financial wellbeing. However, the independent variable of debt management showed no significant influence on the test results since the significance value was larger than 0.05 which was .194. The significant F-Test revealed that the relationship between the dependent variable and the independent variables was linear and the model significantly predicted the dependent variable. The F-test $[F(267,2)=$ 26.729, $p<0.05$ ] indicated an overall significant prediction of the independent variables on the dependent variable (Green \& Salkind, 2006).

<Table 3> Multiple Regression Result
\begin{tabular}{|c|c|c|c|c|}
\hline & $\begin{array}{c}\text { Dependent } \\
\text { variable } \\
\text { (Financial } \\
\text { wellbeing) } \\
\text { (Std. } \boldsymbol{\beta})\end{array}$ & $\begin{array}{c}\text { Significan } \\
\mathbf{c e} \\
\mathbf{( p )}\end{array}$ & Tolerance & VIF \\
\hline Attitude towards money & .344 & .000 & .712 & 1.471 \\
\hline Financial capability & .274 & .033 & .649 & 1.418 \\
\hline Debt management & -.079 & .194 & .812 & 1.221 \\
\hline F value & & 26.729 & & \\
$\mathrm{R}^{2}$ & & .232 & & \\
Adjusted R & & .223 & \\
Durbin Watson & & 1.60 & \\
\hline
\end{tabular}

\subsection{Discussion}

\subsubsection{The Relationship between Attitude towards Money and Financial Wellbeing}

The first research question is to determine the relationship between attitude towards money and financial wellbeing. The result shows significance relationship between these variables. This is consistent with previous research which found that attitudes toward money relates to the financial wellbeing (Furnham, 1984; Furnham Hanley \& Wilhem, 1992). For instance, they found that compulsive spenders have a relatively lower self-esteem than normal consumers, and have beliefs about money which reflect its symbolic ability to enhance self-esteem. This also indicates that changing the attitude towards money is an important catalyst behind the spread of the consumer culture since money has become a symbol of status and achievement, thus, confirming another evidence of its relationship with financial wellbeing. In the current study, most of the respondents seem to have an awareness of their finances and the way they are spending their money. Spending behaviour can also influence the attitude towards money either positively or negatively especially when making decisions about spending money, for necessities or for leisure. In a nutshell, employees would not spend unnecessarily for the sake of others' opinion rather than what they truly needs.

\subsubsection{The Relationship between Financial Capability and Financial Wellbeing}

The second research question is to determine the relationship between financial capability and financial 
wellbeing. The result shows that there was enough evidence to suggest that there is a significant relationship between these two variables. This is consistent with previous research that found there was a significant correlation between financial capability and financial wellbeing in their study of young adults (Serido, Shim, \& Tang, 2013) Current finding shows that financial capability does have an influence over financial wellbeing and most of the respondents do keep track of spending records, immediately settling bills and comparing products, money allocations and investments. In addition, financial knowledge plays an important role in determining financial capability when most respondent agree that they need more information regarding financial matters before making decision on taking financial services such as loans, investments and they do not depend on the services of financial advisers for help. However, while they agree on having more knowledge on financial matters, they were reluctant to be an active information seeker or seek professional advice regarding financial matters, based on the lowest mean score in the questionnaire. This might suggest that, while most researchers found that financial knowledge is crucial to influence financial capability, this findings shows respondents are not supporting the theory of actively seeking financial knowledge, thus placing the factor a slightly lower than the attitude towards money to influence a public servants' financial wellbeing.

\subsubsection{The Relationship between Debt Management and Financial Wellbeing}

The third research question is to determine the relationship between debt management and financial wellbeing. However, the result of the analysis shows that debt management has no significance influence on financial wellbeing. This finding contradicts with a few researchers which found that debt management have a significant influence over financial wellbeing (Campbell, 2006; Lusardi \& Tufano, 2008; Moore, 2003). However, this findings is consistent with Bensaid, Fadila, Roslan, and Yakub' (2013) finding that most people would avoid personal and unnecessary debt as they are exhorted and encouraged to earn their living through legitimate means, eschewing any circumstance that would lead to resorting to borrowing. It is proven by the averagely low mean score on question asked regarding credits and loan that would suggest the respondents would likely to avoid such as "I cannot imagine life without a credit card", "I will not change my expenditure trend even if i have to resort on loans", "I'm willing to spend money imprudently for car accessories than paying the debt I loan", "I am capable to have a lot of items by means of loans" and "In the past 12 months, I do have a problem to payback loan / debt". Another logical explanation is that the Malaysian government servants have the benefit for special government housing loans. While most of the researcher found in their study that debt management involve mostly on housing mortgages, the public servants have minimal worries on the matters since government housing loan scheme is the most attractive scheme in the country and can only be enjoyed by public servants.

\section{Conclusions}

With regard to the influence of attitude towards money and financial capability on financial wellbeing, this study has contributed new information to the body of knowledge on determinants of public servant income management. The present study also confirms the findings of others that improved financial management skills, cash management strategies and futuristic planning styles; in this case, the financial capabilities; may help people avert financial difficulties and increase perceived financial wellbeing. Decreased financial wellbeing may result from the limited use of certain financial management behaviors; which closely refers to the attitude towards money; that is believed by experts to increase financial success. Finally, as most of the respondents were reluctant to resort to loans and credits, government should act immediately to control the rising cost of necessities, but that may be nearly impossible. However, the government or related authorities can enhance their enforcement regarding the price of the controlled items and to put more reasonable fair-price stores nationwide.

\section{References}

Anderloni, L., \& Vandone, D. (2008). Household overindebtedness in the economic literature. Working paper of Dipartimento Di Scienze Economiche Aziendali E Statistiche.

Anderloni, L., \& Vandone, D. (2010). Risk off overindebtedness and behavioural factors, Working paper of Dipartimento Di Scienze Economiche Aziendali E Statistiche.

Atkinson, A., McKay, S., Kempson, E., \& Collard, S. (2006). Levels of Financial Capability in the UK. Results of a Baseline Survey. Bristol: University of Bristol.

Bailey, K. D. (2002). Methods of Social Research. New York: Free Press.

Baumeister, R. F. (2008). Yielding to temptation: Self-control failure, impulsive purchasing, and consumer behavior. Journal Pengguna, 28, 670-676.

Baumeister, R. F., Bratslavsky, E., Muraven, M., \& Tice, D. M. (1998). Ego depletion: Is the active self a limited resource?. Journal of Personality and 
Social Psychology, 74(5), 1252-1265.

Becker, T. A., \& Shabani, R. (2010). Outstanding Debt and the Household Portfolio. The Review of Financial Studies, 23(7), 2900-2934.

Bensaid, B., Fadila, G., Roslan, M. N., \& Yakub, Z. M. Y. (2013). Enduring financial debt: An Islamic perspective. Middle East Journal of Scientific Research, 13(2), 162-170.

Berita Harian (2013). Kesempitan hidup punca ramai cerai: 'Urus kewangan perlu ditekan' dated 12 August 2013 Retrieved January 16, 2018 from http://www2.bharian.com.my/articles/Kesempitanhidu ppuncaramaicerai_Uruskewanganperluditekan_/Artic le/

Berita Harian (2013). Bekas KP Imigresen dijatuhi hukuman penjara dated 30 October 2013 Retrieved January 16, 2018 from http://www.bharian.com.my/articles/BekasKPImigrese ndijatuhi hukumanpenjara/Article/

Besley, T., \& Persson, T. (2010). State Capacity, Conflict, and Development. Econometrica, 78(1), 1-34.

Borg, W. R., \& Gall, M. D. (1979). Applying Educational Research: A Practical Guide. Boston, Mass.: Pearson / Allyn \& Bacon.

Campbell, D., \& Fiske, D. (1959). Convergent and Discriminant Validation. Psychological. 56, 81-105.

Campbell, J. (2006). Household Finance. Journal of Finance, 61(4), 553-1604.

Cheema, A., \& Soman, D. (2006). Malleable mental accounting: The effect of flexibility on the justification of attractive spending and consumption decisions. Journal of Consumer Psychology, 16(1), 33-44.

Christopher, A. N., Marek, P., \& Carroll, S. M. (2004). Materialism and attitudes toward money: An exploratory investigation. Individual Differences Research, 2, 109-117.

Cohen, J. (1988). Statistical Power Analysis for the Behavioral Sciences. (2nd ed.). Hillsdale, NJ: Lawrence Erlbaum Associates Publishers.

Cox, A., Hooker, H., Markwick, C., \& Reilly, P. (2009). Financial Wellbeing in the Workplace. Report 464, Institute for Employment. Retrieved January 16, 2018 from http://www.employment-studies.co.uk/ sub/summary/php?id=464.

Credit Management and Counselling Agency (AKPK) Media Fact Sheet as of July 2013.

Credit Management and Counselling Agency (AKPK) Media Fact Sheet as of May 2014.

Creswell, J. W. (2004). Research Design: Qualitative \& Quantitative Approaches. Thousand Oaks: Sage Publications.
D' Alessio, G., \& Lezzi, S. (2012). Household over-indebtedness; Definition and measurement with Italian data. Working paper of Economic and Financial Statistics Department, Bank of Italy.

Department of the Treasury, President's Advisory Council on Financial Capability. (2012). Interim report of the President's advisory council on financial capability. Retrieved January 16, 2018 from http://www.treasury.gov/resourcecenter/financialeduc ation/Documents/PACFC\%20Interim\%20Report\%20\%20January\%2018,\%202012.pdf

Dixon, M. (2006). Rethinking Financial Capability: Lessons From Economic Psychology And Behavioural Finance. London, UK: Institute for Public Policy Research.

Eagly, A. H., \& Chaiken S. (1993). The Psychology of Attitudes. Orlando, FL, US: Harcourt Brace Jovanovich College Publishers.

Eccles, J., Templeton, J., Barber, B., \& Stone, M. (2003). Adolescence and emerging adulthood: The critical passage ways to adulthood. In M. H. Bornstein, L. Davidson, C. L. M. Keyes, \& K. A. Moore (Eds.), Well-being: Positive development across the life course (pp.383-406). Mahwah, NJ : Lawrence Erlbaum.

Ellen, P. S. (1994). Do we know what we need to know? Objective and subjective knowledge effects on pro-ecological behaviors. Journal of Business Research, 30, 43-52.

Fazli, M. S., \& Leila, F. (2003). Predictors of Financial Well-Being among Malaysian Employees: Examining the Mediate Effect of Financial Stress. Journal of Emerging Economies and Islamic Research. 1, 23-32.

Fazli, M. S., \& Mumtazah, O. (2010). Financial literacy: Research, education and policy implication. Family and Consumer Sciences Research Journal, 14, 53-71.

FINRA Investor Education Foundation (2009). Financial Capability in the United States: National SurveyExecutive Summary. Washington, DC. Retrieved January 16, 2018 from http://www.finrafoundation.org/web/groups/foundation /@foundation/documents/foundation/p120535.pdf

Fogel, J., \& Schneider, M. (2011). Credit card use: disposable income and employment status. Young consumers. 12(1), 5-14.

Furnham. A. (1984). Many Sides of the Coin: the Psychology of Money Usage. Personality and Individual Differences, 5, 501-509.

Garman, E. T., Leech, I. E., \& Grable, J. E. (1996). The negative impact of employee poor personal financial behaviors on employers. Financial 
Counselling and Planning, 7, 157-168.

Green, S. B., \& Salkind, N. J. (2006). Using SPSS for Windows and Macintosh; Analyzing and Understanding Data, Fifth Edition, Upper Saddle River, New Jersey: Pearson / Prentice Hall.

Gujarati (2005). Basic Econometrics (Translation by Sumarno Zain). Jakarta: Erlangga.

Hair, J. F., \& Bush, R. P. (2003). Marketing Research Within a Changing Information Environment. New York: McGraw-Hill.

Hanley, A., \& Wilhelm, M. (1992). Compulsive Buying: An exploration into self-esteem and money attitudes. Journal of Economic Psychology, 13, 5-18.

Hanson, A., Forsell, Y., Hochwalder, J., \& Hilleras, P. (2008). Impact of changes in life circumstances on subjective well-being in an adult population over a 3-year period. Public Health, 122, 1392-1398.

Harian Metro (2011). Nikah Tebus Hutang Karpet dated 3 February 2011 Retrieved January 16, 2018 from http://www.hmetro.com.my/articles/Nikahtebushutang karpet/Article

Henry, G. T. (1990). Practical Sampling. Newbury Park. CA: Sage.

Kerlinger, F. N. (1973). Foundations of Behavioral Research (2nd ed.). American Problem Series. New York: Holt, Rinehart and Winston, Inc.

Kim, J., Garman, E. T., \& Sorhaindo, B. (2003). Relationships among credit counselling, financial well-being and health. Consumer Interests Annual, 49, 1-12.

Knight, J. A. (1968). For the Love of Money. New York: J. B. Lippincott Co.

Krejcie, R. V., \& Morgan, D. W. (1970). Determining Sample Size for Research Activities. Educational and Psychological Measurement. The NEA Research Bulletin, 38, 99.

Legge, J., \& Heynes, A. (2009). Beyond Reasonable Debt: A Background Report on the Indebtedness of New Zealand Families. Social Policy Journal of New Zealand, 35, 65-70.

Leila, F., \& Laily, P. (2011). A Comparative Study in Money Attitude among University Students: A Gendered View. Journal of American Science, 76) 1144-1148.

Lindgren, H. C. (1980). Great Expectations: The Psychology of Money, Los Altos: William Kaufmann, Inc., 58-99.

Lown, J. M., \& Ju, I. S. (1992). A Model of Credit Use and Financial Satisfaction. Journal of Financial Counseling and Planning, 3, 105-125.

Lusardi, A. (2011). Americans' Financial Capability. National Bureau of Economic Research Reports,
Harvard Business School.

Lusardi, A., \& Tufano, P. (2008). Debt Literacy, Financial Experiences and Over-indebtedness. (NBER Working Paper No. 14808). Cambridge, MA: National Bureau of Economic Research.

Malhotra, M. K., Steel, D. C., \& Grover, V. (2007). Decision Sciences: Important Strategic and Tactical Manufacturing Issues. 25(2), 121-129.

Mason, H. K. (2002). Consumer Credit and Spending Trends. Bernstein Research. Sanford: Bernstein \& Co.

Moore, D. (2003). Survey of Financial Literacy in Washington State: Knowledge, Behavior, Attitudes, and Experiences. Technical Report No. 03-39, Social and Economic Sciences Research Center, Washington State University.

Mottola, G. R. (2014). The Financial Capability of Young Adults - A Generational View. FINRA Foundation Financial Capability Insights. Washington, DC: FINRA Investor Education Foundation.

Nuraini, A., Fazli, M. S., Husniyah, A. R., Mohd Amim, O., Mastura, M. A., \& Nurul Farhana, Z. (2013). Pengurusan Kewangan Dalam Kalangan Pekerja Muda, Jurnal Pengguna Malaysia, 21, 45-51.

Opsahl, R. L., \& Dunnette, M. D. (1966). The role of financial incentives in industrial motivation. Psychological Bulletin. 66, 95-116.

Polit, D. F., \& Beck, C. T. (2004). Nursing Research: Principles and Methods (7th Ed.). Philadelphia: Lippincott Williams and Wilkins.

Porter, N. M., \& Garman, E. T. (1993). Testing a Conceptual Model of Financial Well-Being. Financial Counselling and Planning, 4, 135-165.

Raduan, C. R. (2002). Japanese-Style Management Abroad: The Case of Malaysian Subsidiaries. Kuala Lumpur: Prentice Hall.

Raju, P. S., Lonial, S. C., \& Mangold, W. G. (1995). Differential effects of subjective knowledge, objective knowledge, and usage experience on decision making: An exploratory investigation. Journal of Consumer Psychology, 4(2), 153-180.

Remund, D. L. (2010). Financial literacy explicated: The case for a clearer definition in an increasingly complex economy. The Journal of Consumer Affairs, 44(2), 276-295.

Roberts, J. A., \& Jones, E. (2001). Money Attitudes, Credit Card Use, and Compulsive Buying among American College Students. Journal of Consumer Affairs, 35, 213-240.

Sabitha, M. (2005). Kaedah penyelidikan sains sosial. Petaling Jaya, Malaysia: Prentice Hall Pearson.

Salkind, N. J. (2006). Exploring Research (6th Ed.). 
Upper Saddle River, New Jersey: Pearson.

Sekaran, U. (2000). Research Methods for Business: $A$ Skill Building Approach. New York: John Wiley and Sons.

Sekaran, U. (2003). Research Methods for Business, a Skill- Building Approach (4th Ed.). New York: John Wiley and Sons Inc.

Sekaran, U., \& Bougie, R. (2013). Research Methods for Business: $A$ Skill Building Approach (6th Ed.). New York: John Wiley and Sons Inc.

Serido, J., Shim, S., \& Tang, C. (2013). A developmental model of financial capability: A framework for promoting a successful transition to adulthood. International Journal of Behavioral Development. 37, 113-121.

Sherraden, M. S. (2010). Financial Capability: What Is It and How It Can Be Created?. St. Louis, MO: Washington University, Center for Social Development. Strumpel, B. (1976). Economic Means for Human Needs. Ann Arbor, MI: Institute for Social Research.

Shim, J. K., \& Siegel, J. G. (1995). Dictionary of Economics. New York: John Wiley \& Sons.

Tashakkori, A., \& Teddlie, C. (1998). Mixed Methodology: Combining Qualitative and Quantitative Approaches. New York: Sage Publications.

Thums, S. L., Newman, B. M., \& Xiao, J. J. (2008). Credit card debt reduction and development stages of the lifespan. Journal of Personal Finance, 6, 86-107.

Utusan (2014). Hutang Anggota TLDM Membimbangkan Abdul Aziz dated 4 October 2014 Retrieved January 16, 2018 from http://www.utusan.com.my/ berita/nasional/hutang-anggota-tldm-membimbangka n-abdul-aziz-1.11596

Wernimont, P. F., \& Fitzpatrick, S. (1972). The meaning of money. Journal of Applied Psychology, 56(3), 218-226.

Whitsett, C. H. (2012). High debt, low information: A survey of student loan borrowers. NERA Economic Counsulting on Behalf of Young Invicibles.

Williams, F. L., Haldeman, V., \& Cramer, S. (1996). Effect of financial concerns upon workplace behaviour and productivity. Financial Counselling and Planning, 7, 147-155.

Zafar, U. A., Ishak. I., Sadiq, S., Ibrahim, T., \& Hasbalaila, A. (2010). Malaysian consumers' credit card usage behaviour. Asia Pacific Journal of Marketing and Logistics, 22(4), 528-544.

Zeti, A. A. (2013). Report On Financial Stability And Payment Systems of 2012 submitted to the Prime Minister on 20th March 2013. Central Bank of Malaysia.

Zikmund, W. G. (2003). Business Research Methods (7th Ed.). Kentucky: Thomson Southwestern. 